\title{
Pelatihan Internet Market Place Bagi Pengrajin Tenun Songket Desa Sukerare Kecamatan Jonggat Lombok Tengah
}

\author{
Djul Fikry Budiman*, A.Sjamsjiar Rahman, M. Samsyu Iqbal, Misbahuddin, L. \\ Ahmad S. irfan akbar, Giri Wahyu Wiriasto
}

Jurusan Elektro, Universitas Mataram, Indonesia;

Kata Kunci: acara adat, online, pengepul, media sosial

\begin{abstract}
Abstrak: Songket adalah jenis tenunan tradisional di Indonesia yang umumnya digunakan pada acara-acara resmi terutama acara resmi yang berkaitan dengan acara adat. Salah satu daerah penghasil kain songket dan tenun ikat yang sangat terkenal di pulau lombok adalah desa Sukerare, kecamatan jonggat kabupaten lombok tengah. Pangsa pasar yang luas tidak hanya pangsa pasar lokal tetapi juga dari mancanegara, tidak menjadikan pengrajin tenun songket di desa sukerare sukses dalam pemasaran hasil produksi. Hal tersebut terjadi karena pesanan yang didapatkan baik lokal maupun mancanegara tidak langsung kepada mereka, tetapi hanya terbatas pada pesanan pengepul/perantara. pelatihan internet market place bagi pengrajin tenun songket di desa Sukerare, dilakukan untuk memberikan pengenalan kepada kelompok pengrajin agar mampu memasarkan produk yang dihasilkan ke taraf nasional dan internasional secara online berbasis internet. Hasil dari pelatihan internet market place, pengrajin mampu membuat dan mengelola toko online berbasis internet menggunakan media sosial.
\end{abstract}

Korespondensi: djulfikry@unram.ac.id

\section{PENDAHULUAN}

Songket adalah jenis tenunan tradisional di Indonesia, dan digolongkan dalam keluarga tenunan brokat. Songket ditenun dengan tangan menggunakan benang emas dan perak. Kain songket pada umumnya digunakan pada acara-acara resmi terutama acara resmi yang berkaitan dengan acara adat. Kain Songket ini dipakai sebagai bagian dari pakaian tradisional suku Sasak yang bernama Baju Lambung (baju wanita), baju adat khas Lombok dengan motif hitam polos dengan variasi bawahan yang beragam, biasanya berbentuk selendang, ikat pinggang atau aksesoris lainnya. Sedangkan untuk yang pria biasanya menggunakan songket sebagai bawahan (pasangan baju adat Tegodek Nongkeq) yang diatur sedemikian rupa sehingga indah dipandang. kain songket identik dengan kain tradisional yang terikat oleh ketentuan atau nilai-nilai tertentu yang mengikat pengerajin tenun songket itu sendiri.

Kata songket berasal dari istilah sungkit dalam bahasa Melayu dan bahasa Indonesia, yang berarti "mengait" atau "mencungkil". Hal ini berkaitan dengan metode pembuatannya, mengaitkan dan mengambil sejumpit kain tenun dan kemudian menyelipkan benang emas. Istilah menyongket berarti menenun dengan benang emas dan perak. Songket adalah kain tenun mewah yang biasanya dikenakan saat kenduri (perayaan/pesta). Meskipun berasal dari kerajinan tradisional, industri songket merupakan kerajinan yang terus hidup dan dinamis. Sebagai benda seni, songket pun sering dibingkai dan dijadikan penghias ruangan. 
Penerapan kain songket secara modern sangat beraneka ragam, mulai dari tas wanita, peci, bahkan kantung ponsel.

Salah satu daerah penghasil kain songket dan tenun ikat yang sangat terkenal di pulau lombok adalah desa Sukerare. Desa sukerare adalah sebuah desa penghasil tenun ikat dan songket yang terletak di Kecamatan Jonggat, Kabupaten Lombok Tengah. Desa Sukerare hanya berjarak $20 \mathrm{~km}$ dari Kota Mataram. Masyarakat di Desa Sukerare sebagian besar menjadi pengrajin tenun dan songket dan menjadi sentral pembuatan tenun di Pulau Lombok. Alat tenun yang digunakan oleh masyarakat Sukerare masih menggunakan alat tradisional. Masyarakat Sukerare menjadi terkenal sebagai pengusaha Tenun dan Songket sebagai kerajinan rumah atau Home Industri yang terkenal hingga ke seluruh daratan Lombok. Motif kain songket dan tenun ikat yang berbeda dari yang lain membuat kain songket dan tenun ikat Desa Sukerare memiliki banyak peminat, dan kini songket Sukerare merambah ke pasar luar negeri/mancanegara.

Pangsa pasar yang luas tidak hanya pangsa pasar lokal tetapi juga dari mancanegara tidak menjadikan pengrajin tenun songket di desa sukerare sukses dalam pemasaran hasil produksi. Hal tersebut terjadi karena pesanan yang didapatkan baik lokal maupun mancanegara tidak langsung mereka nikmati tetapi biasanya hanya terbatas pada pesanan pengepul/perantara. Pengrajin sangat tergantung kepada pengepul baik pesanan maupun harga sehingga harga sangat di tentukan oleh pengepul. Selain pesanan pengepul, para pengrajin mendapatkan konsumen dari wisatawan yang membeli langsung. Masalah pemasaran yang tidak menentu dan ketergantungan pada pengepul juga disebabkan jarangnya mereka melakukan promosi produk tentang hasil karya mereka.

Masalah dalam pemasaran yang belum tertata dengan baik dan pangsa pasar yang tak tentu, hanya terbatas pada pengepul, sedangkan pangsa pasar sudah mencakup para wisata mancanegara. Dengan latar belakang permasalahan tersebut, dalam bidang pemasaran dipandang perlu diupayakan ke arah market place secara global melalui Internet. Dengan demikian, konsumen dapat secara langsung berhubungan dengan pengerajin darimana dan kapan saja. Hal ini akan menjamin harga yang lebih pasti diperoleh konsumen, dan sebaliknya pihak pengerajin tidak akan dipermainkan oleh pengepul. Salah satu alternatif media promosi sekaligus sebagai market place online ini, jika dapat berjalan dengan baik, diharapkan permintaan produk menjadi bertambah sehingga proses produksi akan meningkat. Dengan meningkatnya proses produksi kebutuhan akan tenaga kerja akan dapat mengurangi pengangguran di sekitarnya. Dampak eksistensi pengerajin ini terhadap lingkungannya diharapkan mampu meningkatkan kesejahteraan masyarakat disekitarnya.

\section{METODE KEGIATAN}

Untuk memberikan pengetahuan yang lebih dalam penggunaan media sosial sebagai salah satu media promosi, tim pengabdian pada masyarakat menggunakan medote pelatihan untuk membuat market place dan bagaimana mengelola market place yang dibuat tersebut kepada warga Desa Sukerare. Tahapan pelatihan yang dilakukan diperlihatkan pada tabel 1.

Tabel 1. Tahapan Pelatihan

Tahap Nama Tahapan Kegiatan




$\begin{array}{lll}\text { 1. } & \text { Koordinasi } & \begin{array}{l}\text { Mengadakan pertemuan dengan aparat desa, } \\ \text { sosialisasi jenis kegiatan, tempat dan waktu } \\ \text { pelaksanaan }\end{array} \\ \text { 2. } & \text { Jenis Pelatihan } & \begin{array}{l}\text { Pelatihan Membuat market place menggunakan } \\ \text { internet }\end{array} \\ \text { 3. } \quad \text { Penentuan Lokasi Pelatihan } & \begin{array}{l}\text { Balai Desa Sukerare Kec. Jonggat Kab. Lombok } \\ \text { Tengah }\end{array} \\ \text { 4. } & \text { Jumlah Peserta } & 15 \text { peserta } \\ 5 . \quad \text { Lama Pelatihan } & 1 \text { Hari } \\ 6 . \quad \text { Monitoring } & \begin{array}{l}\text { Pendampingan dalam membuat dan mengelola } \\ \text { market place } \\ \text { Jumlah keberhasilan peserta pelatihan membuat } \\ \text { halaman market place }\end{array} \\ \text { 7. } \quad \text { Evaluasi } & \end{array}$

Dalam pemaparan materi pelatihan pembuatan internet market place sebagai sarana promosi, tim pengabdian merumuskan dan membuat materi yang sesuai dengan kondisi masyarakat di Desa Sukerare. Urutan materi yang diberikan pada pelatihan tersebut dapat dilihat pada tabel 2.

Tabel 2. Materi Pelatihan

\begin{tabular}{ll}
\hline No. & Materi \\
\hline 1. & Pengenalan Internet Market place \\
2. & Facebook sebagai sarana market place \\
3. & Pembuatan halaman untuk promosi usaha di facebook \\
4. & Pengelolaan halaman dan cara promosi \\
\hline
\end{tabular}

\section{HASIL DAN PEMBAHASAN}

Pelaksanaan pelatihan PPM dengan Judul "Pelatihan Internet Market Place Bagi Pengrajin Tenun Songket Desa Sukerare Kecamatan Jonggat Lombok Tengah" ini telah berjalan dengan baik. Dari undangan untuk peserta yang hanya 15 orang dihadiri oleh 20 orang ditambah dengan antusiasnya aparat desa yang ikut menjadi peserta pelatihan. Bersedianya salah satu peserta dari aparat desa untuk memceritakan pengalaman pribadi dalam menggunakan internet sebagai sarana promosi, memberikan nilai positip kepada rekan sesama pengrajin songket di desa tersebut. Peserta pelatihan adalah para penenun yang ratarata memiliki kelompok penenun dan aktif memasarkan hasil tenunan para pengrajin songket di Sukerare. Suasana pelatihan yang dilakukan pada tanggal 3 September 2019 tersebut diperlihatkan pada gambar 1 . 

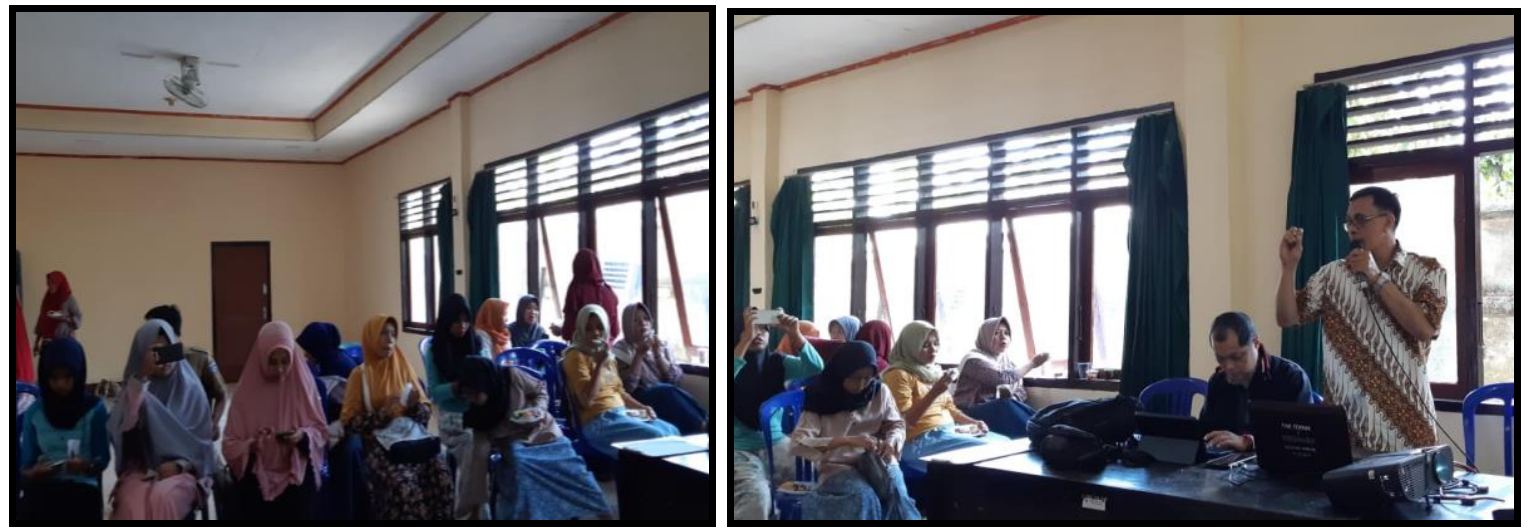

Gambar 1. Pelaksanaan kegiatan Pelatihan Internet Market Place

\section{KESIMPULAN DAN SARAN}

\section{Kesimpulan}

Kesimpulan yang dapat diambil dari pelaksanaan kegiatan ini adalah:

1. Secara keseluruhan, mulai dari persiapan hingga pelaksanaan, pelatihan dirasakan berjalan dengan baik. Antusias aparat desa dan peserta dalam mengikuti pelatihan dapat dilihat dari cara mereka melatih diri menggunakan perangkat android yang mereka miliki.

2. Pelatihan yang dilaksanakan selama 1(satu) hari dirasakan belum cukup walaupun mampu memberikan pemahaman lebih dalam meggunakan fungsi media sosial sebagai sarana pemasaran dan promosi ke seluruh dunia.

\section{Saran}

Pelaksanaan kegiatan serupa agar lebih ditingkatakan baik waktu maupun jadwal yang diberikan. Pemerintah daerah setempat diharapkan dapat lebih intensif memberikan pelatihan teknologi untuk pemasaran hasil tenunan warga desa, dengan harapan tenun Desa Sukerare mampu lebih berkiprah secara nasional maupun internasional

\section{UCAPAN TERIMA KASIH}

Kami Tim PPM Pelatihan Internet Market Place mengucapkan terima kasih kepada aparat khususnya sekretaris desa yang telah memberi dukungan baik moril dan materil terhadap pengabdian ini.

\section{DAFTAR PUSTAKA}

Tungga Wika Atmaja, Agustiana Wikrama. 2013. Perkembangan Motif Kerajinan Tenun Songket Di Desa Sidemen Karangasem Bali. Tersedia pada https://ejournal.undiksha.ac.id/index.php/JJPS/article/view/1007/874

Santoso, Soegeng. (2007). Kiat dan Strategi Menulis Karya Ilmiah. Universitas Negeri Jakarta. Makalah disampaikan pada pelatihan penulisan Karya Tulis Ilmiah Bagi Dosen-dosen PPSD FIP UNY. 